\title{
CLASSROOM INTERACTION IN ENGLISH LESSON \\ BASED ON FLANDER'S INTERACTION \\ CATEGORIES (FIAC)
}

\author{
*Elfridayani Purba \\ **Prof. Amrin Saragih,M.A., Ph.D \\ **Dr. Siti Aisyah Ginting, M.Pd
}

\begin{abstract}
Purba, Elfridayani. Registration Number: 2123321024. Classroom Interactio $n$ in English Lesson Based on Flander's Interaction Categories (FIAC). A Thesis. English Educational Program, State University of Medan, 2016.
\end{abstract}

This study focuces on analyzing the process of classroom interaction through Flanders Interaction Analysis Category (FIAC) model. The objective was to describe how the teacher and students use the categories of classroom interaction in English class by using Flanders Interaction Analysis Category (FIAC) model. The data was found based on the data transcription. The source of the data was the utterances between English teacher and 7th grade students at SMP N 1 SEIBAMBAN. The instruments for data collection were observation, video recording, and note talking. The data analysis applied descriptive qualitative research. It was found that the total percentage each categories classroom interaction were accepts feelings $(0.57 \%)$, praise and encourages (1.34\%), accepts or uses the ideas of the students (0.19\%), asks questions (13.74\%), lecturing $(7.06 \%)$, giving directions $(30.9 \%)$, criticizing or justifying authority (3.91\%), students talk-response $(28.81 \%)$, students talk-initiation $(0.29 \%)$, and silence or confusion $(13.17 \%)$. It showed that students participated in the interaction process.

Keywords: Teacher Talk, Students Talk, Flanders Interaction Analysis Categories (FIAC) model.

\footnotetext{
*Graduate Status

**Lecturer Status
} 


\section{INTRODUCTION}

\section{Background of the Study}

Interaction simply means acommunication which involves more than one person. The importance of interaction is explained by Brown (2000:165): Through interaction between teacher and students can exchange thought, feelings, and ideas resulting in a reciprocal effect on each other in the classroom. Moreover, Lister (2007) states that interaction makes the students be able to test their communicative success through exchanging information with the teacher or among the students themselves.

Furthermore, to have a good interaction, students should realize speech function. To initiate a talk, students use not only question but also statement, command or offer to initiate to talk. Speech functions need to be introduced to the students in order to give them more knowledge on how to maintain successful interaction.

Flander's Interaction Analysis Categories (FIAC) as a model of classroom interaction used to find out how dothe teacherand students' talking time during the teaching and learning process (Flanders, 1970). In addition, it means the researcher who wanted to use FIAC model had to use every three seconds to decide which one of the best category of teacher talk, students talk, or silence should be written down to put in the observation sheet.

Pujiastuti's (2013) study focused on An Analysis of Teacher Talk and Student Talk in English for Young Learners (EYL). She found that all of the teacher talk categories of FIAC were revealed covering giving direction, lecturing, 
asking questions, using student's ideas, praising, criticizing student's behaviour and accepting feelings. However, giving direction and lecturing were found as the most frequently used categories among all. To ensure this idea, this study was conducted with the title of "Classroom Interaction in English Lesson based on Flander's Interaction Analysis Categories (FIAC) model".

\section{REVIEW OF RELATED LITERATURE}

Brown (1994: 159) defines interaction as the collaborative exchange thoughts, feelings or ideas between two or more people resulting in a reciprocal effect on each other. Thomas (1996:7) says that although interaction is a two-way process, it is not only in the form of action and reaction. By the condition above, so the classroom interaction is a two - way process between the teacher and students and among students during interaction in the learning process in which teacher influences the learners. Flanders Interaction Analysis Categories (FIAC) is a Ten Category System of communication which are said to be inclusive of all communication possibilities. There are seven categories used when the teacher is talking (Teacher talk) and two when the pupil is talking (Pupil talk) and tenth category is that of silence or confusion. 
Table 2.1 Flander's Interaction Analysis Categories (FIAC) model

\begin{tabular}{ll}
\hline Teacher Indirect & 1. ACCEPTS FEELING: accepts and clarifies the tone of \\
talk & influence \\
the students in an unthreatening manner. Feelings may \\
be positive or negative. Predicting or recalling feelings \\
are included. \\
2. PRAISES OR ENCOURAGES: praises or encourage \\
student action or behavior. Jokes that release tension, \\
but not at the expense of another individual, nodding \\
head or saying 'um hm?' or ''go on" are included. \\
ACCEPTS OR USES IDEAS OF STUDENT: \\
clarifying, building, or developing ideas suggested by a \\
student. As teacher brings more of his own idea into \\
play, shift to category five \\
4. ASKS QUESTIONS: asking a question about content or \\
procedure with the intent that a student answer.
\end{tabular}

As illustrated in table 1.1, there are ten categories which are divided into teacher talk, student talk, and silence or confusion. In teacher talk, the categories are accpeting feeling, praising and encouraging, accepting or using ideas of students, asking questions, lecturing, giving directions, and criticizing or 
justifying authority. Meanwhile, students talk categories are responding and initiating.

\section{Relevant Studies}

In composing this proposal, there are some previous researches related to this study which become the references in composing this proposal.

An analysis on the Speaking Classroom Interactions at the Tenth grade of SMA Negeri 7 Surakarta in The Academic Year 2006/2007 by Asmara (2007) found that during the interaction, the percentage of teacher's talk time was higher than student's talk time in the speaking classroom interactions. The interaction pattern happening in the classroom showed that the teacher was active while the students were passive.

Besides that, Mujahidah (2012) conducted research on the Classroom Interaction during the English Teaching - Learning Process at the Eight grade of SMPN 1 Banjarmasin found that during interaction, teacher dominating the interaction. The category mostly applying with "asking question" and English is a language mostly used.

The other studies about Classroom Interaction: An Analysis of Teacher Talk and Student Talk in English for Young Learners (EYL). Pujiastuti (2013) who found that all of the teacher talk categories of FIAC were revealed covering giving direction, lecturing, asking questions, using students's ideas, praising, criticizing student's behaviour and accepting feelings. However, giving direction and lecturing were found as the most frequently used categories among all. 
Almira (2016) also studied about An Analysis of Classroom Interaction by Using Flanders Interaction Analysis Categories System (FIACS) Techniques at SMPN28 Bandar Lampung found that a research that the objective was to describe the interaction between the teacher and learners while they are in the classroom. The result showed that giving direction was the most frequently used by the teacher talk. In students talk, students response specific was the most frequently used.

The other studies about The Teacher and Learner Talk in the Classroom Interaction of grade VIII A SMPN 2 Cepiring Kendal. Nafrina (2007) conducted a study that the objective was to describe the interaction between the teacher and learners while they are in the classroom. The result of this study shows that the teacher is dominant in the classroom interaction.

Nugroho (2010) also studied about Interaction in English as a Foreign Language Classroom (A Case of Two State Senior High Schools in Semarang) found that English teaching and learning process in both senior high schools were teacher centered, the general characteristics of classroom interaction encompassed content cross, student participation, student talking time (STT), indirect ratio which was differentiated by the different number of percentage, teacher talking time (TTT), teacher support, teacher control and period of silence, and characteristic of classroom interaction was significantly influenced by the type of talking time performed by teachers and students during the interaction. 


\section{RESEARCH METHODOLOGY AND FINDINGS}

\section{Methodology}

This study was conducted using the descriptive qualitative design. The data in form of description of quality such as good or bad and not of that based by the scoring systems using numbers and the presenting collected data and other real-world events and experiences that unfold in a particular environment (Patton, 1990:41). The data was obtained from the transcription, which is analyzed from Flanders Interaction Analysis Categories (FIAC) model.

\section{Technique of Data Analysis}

Data analysis is a process where researcher systematically searches and arranges the data in order to increase her understanding of it. This research followed some steps of analizing the data as stated by Flanders (1970):

1) Filling in the data recorded sheet

2) Getting the backup data by coding the verbal interaction

3) Plotting the coded data into a matrix

4) Analyzing the categories of teacher talk and students talk based on Flander's formulated.

\section{Research Procedure}

The steps to analyze the data used in this research were:

(a) Identifying the data transcription

The researher identified the transcription from video recording. 
(b) Classifying the data

The researcher classified the data using the Flander's Interaction Analysis Category (FIAC) model.

(c) Giving a code number

The researcher gave a code number for the data. Every interaction is recorded one number. It was showed from the table 1.2 below :

Table 3.1 The example of Transcription Interaction between Teacher and Students.

\begin{tabular}{|l|c|}
\hline \multicolumn{1}{|c|}{ Interaction in English Class } & Coded Number \\
\hline Teacher $\quad$ : What is Month? & 4 \\
Students $\quad$ : Bulan, Sir.. & 8 \\
Teacher $\quad$ : How many Months in Year? & 4 \\
Students : Twelve, Sir. & 8 \\
Teacher $\quad$ : Please, Says... & 6 \\
Students : January, February, March, April, May, June, & \\
July,August,September, October, November, December. & 8 \\
\hline
\end{tabular}

(d) Pairing the data

The researcher paired the number of categories of interaction. While, at the beggining or/ at the and of the series number added 10th category.

(e) Plotting the code number into a matrix

The researcher entered the firsth pair in one matrix, the second pair represented another value, and so on. After that, the researcher calculated the categories of classroom interaction based Matrix.

(f) Drawing conclusion from the response

The researcher described the techer talk and students talk categories using Flander's Interaction Analysis Category (FIAC) based on the data. 


\section{Findings}

Based on the analysis of the data that had been found through observation in the classroom interaction, it concluded that:

1) The data was found from the data transcription between the teacher and the students in English Classroom Interaction at 7th grade students.

2) The result of analysis was Classroom Interaction Model that suggested by Flanders model (Flander's Interaction Analysis Categories).

3) Based on the Flander's Interaction Analysis Categories Model, it found that the example of data transcription can be seen in the table below :

Table 4.1 Classroom Interaction Transcription A

\begin{tabular}{|c|c|c|c|}
\hline $\begin{array}{l}\text { Categories } \\
\text { Number }\end{array}$ & 1 & $\mathrm{~T}$ & $\begin{array}{l}\text {-We start our study and listen it. } \\
\text {-Alright, persoalantugasnyaterimakasih } \\
\text { yang sudahmengerjakantugas. } \\
\text {-Your homework will be checked. } \\
\text {-So, we continues our lesson. } \\
\text {-Kalaukemarenkanmasihada yang } \\
\text { belumselesai. } \\
\text {-Yesterday we studied about month. } \\
\text {-What is Month? } \\
\text { (researcher classifed as } 6 \text { and a 4) }\end{array}$ \\
\hline 8 & 2 & $\mathrm{~S}$ & $\begin{array}{l}\text {-Month... } \\
\text { (researcher recorded a 8) }\end{array}$ \\
\hline 4 & 3 & $\mathrm{~T}$ & $\begin{array}{l}\text { - Months of the Year. What is that?(the } \\
\text { researcher recorded a } 4 \text { for a question) }\end{array}$ \\
\hline 8 & 4 & $\mathrm{~S}$ & $\begin{array}{l}\text {-Bulandalamsetahun. } \\
\text { (the researcher recorded } 8 \text { for a respond }\end{array}$ \\
\hline 4 & 5 & $\mathrm{~T}$ & $\begin{array}{l}\text {-How many months in } 1 \text { year? } \\
\text { (the researcher recorded a } 4 \text { for a } \\
\text { question) }\end{array}$ \\
\hline 8 & 6 & $\mathrm{~S}$ & $\begin{array}{l}\text {-Twelve months Sir... } \\
\text { (The researcher recorded 8) }\end{array}$ \\
\hline
\end{tabular}


Table 4.2 Classroom Interaction Transcription B.

\begin{tabular}{|ccll|}
\hline $\begin{array}{c}\text { Categories } \\
\text { Number } \\
6,4\end{array}$ & 7 & $\mathrm{~T}$ & $\begin{array}{l}\text {-Please read the first month in English. } \\
\text {-The first Month? } \\
\text { (The researcher recorded two 6 and a 4) }\end{array}$ \\
\hline 8 & 8 & $\mathrm{~S}$ & $\begin{array}{l}\text {-January } \\
\text { (the researcher recorded a } 8 \text { for an } \\
\text { answer) }\end{array}$ \\
\hline 4 & 9 & $\mathrm{~T}$ & $\begin{array}{l}\text {-The second Month? } \\
\text { (the researcher recorded a } 4 \text { for a } \\
\text { question) }\end{array}$ \\
\hline 8 & 10 & $\mathrm{~S}$ & $\begin{array}{l}\text { - February. } \\
\text { (the researcher recorded a } 8 \text { for a } \\
\text { question) }\end{array}$ \\
\hline 4 & 11 & $\mathrm{~T}$ & $\begin{array}{l}- \text { The third Month? } \\
\text { (the researcher recorded a } 4 \text { for } \\
\text { question) }\end{array}$ \\
\hline 8 & 12 & $\mathrm{~S}$ & $\begin{array}{l}\text { - March... } \\
\text { (The researcher recorded } 8 \text { ) }\end{array}$ \\
\hline
\end{tabular}

Table 4.3 Classroom Interaction Transcription C.

\begin{tabular}{|clll|}
\hline $\begin{array}{c}\text { Categories } \\
\text { Number } \\
4\end{array}$ & 13 & $\mathrm{~T}$ & $\begin{array}{l}\text { - The fourth Month? } \\
\text { (The researcher recorded two } 6 \text { and a 4) }\end{array}$ \\
\hline 8 & 14 & $\mathrm{~S}$ & $\begin{array}{l}\text {-April } \\
\text { (the researcher recorded a } 8 \text { for an } \\
\text { answer) }\end{array}$ \\
\hline 4 & 15 & $\mathrm{~T}$ & $\begin{array}{l}\text {-The fifth Month? } \\
\text { (the researcher recorded a } 4 \text { for a } \\
\text { question) }\end{array}$ \\
\hline 8 & 16 & $\mathrm{~S}$ & $\begin{array}{l}\text {-March } \\
\text { (the researcher recorded a } 8 \text { for a } \\
\text { question) }\end{array}$ \\
\hline 4 & 17 & $\mathrm{~T}$ & $\begin{array}{l}- \text { The sixth Month? } \\
\text { (the researcher recorded a } 4 \text { for } \\
\text { question) }\end{array}$ \\
\hline 8 & 18 & $\mathrm{~S}$ & $\begin{array}{l}- \text { June... } \\
\text { (The researcher recorded } 8 \text { ) }\end{array}$ \\
\hline
\end{tabular}

Based on the table above, each number described the type of verbal interaction and who is speaking. Every time the verbal interaction change, a new number is recorded. If the same verbal interaction continued for more than three seconds, the same number will be recorded. 
After the data transcription iscoded, so the researcher paired the number of categories of interaction. While, at the beggining or/ at the end of the series number added 10th category. It can be seen based on the figure below:

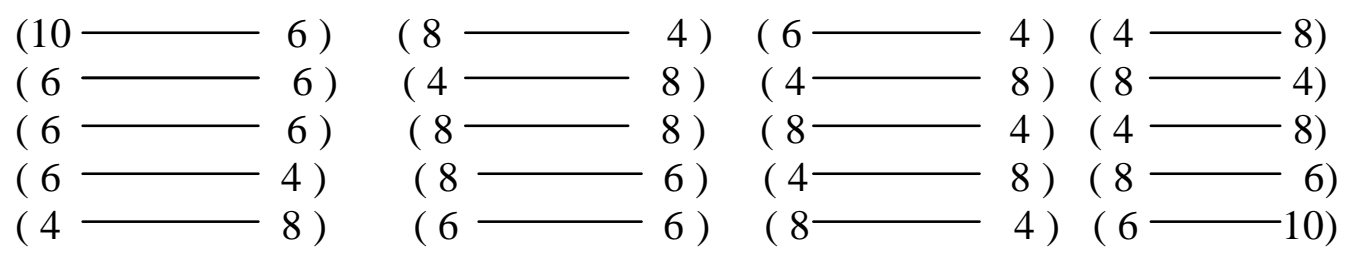

Figure 4.1 Matrix of Pairing the Code Number.

From the figure above, it showed the first pair represented one point on the matrix, the second pair represented another point on the matrix, the third pair represented to others point on the matrix, and so on. The matrix consisted of ten columns and ten rows. Each column and rows represented on of the ten categories of the Flander's coding. Next, the researcher calculated the result of each category of classroom interaction in a percentage by using the Flander's formulated. It showed based on the table below:

Figure 4.2 The result categories of teacher talk and students talk

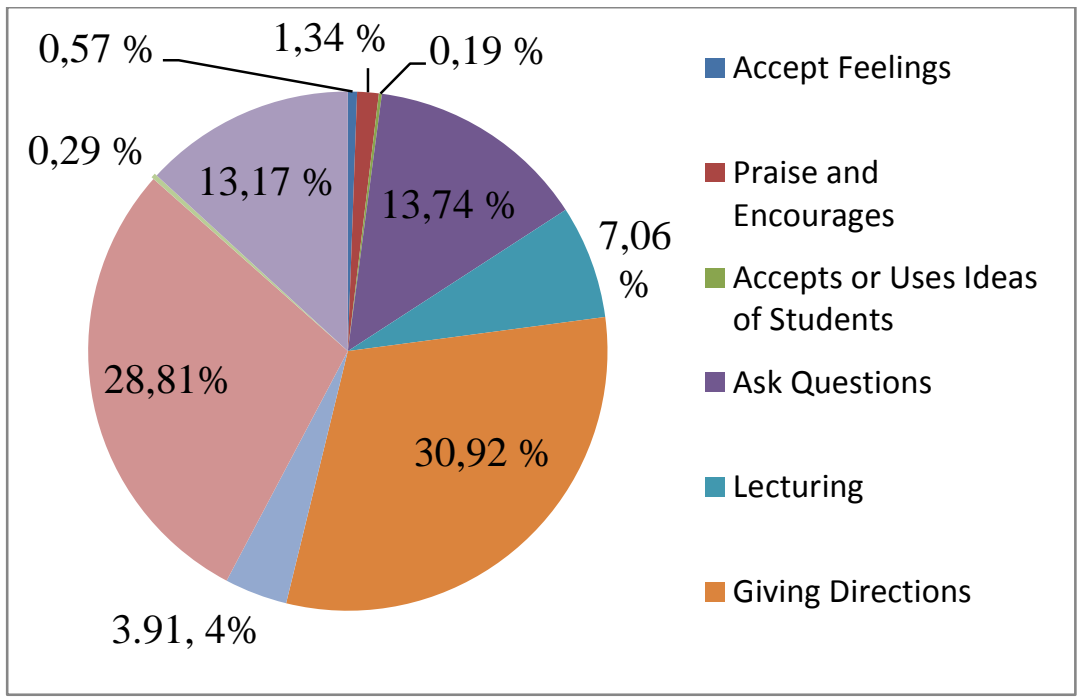


Based on the Table above, we can see that the most dominant category in Teacher Talk was Giving Direction (30.92\%).While the lowest category in teacher talk used in the classroom was accepts or uses ideas of students $(0.19 \%)$. The dominant category in Students talk was student talk-response $(28.81 \%)$. While the lowest category was student talk-initiation $(0.19 \%)$.

\section{CONCLUSIONS AND SUGGESTIONS}

\section{Conclusions}

After analyzing the data of teacher and students interaction in the classroom, a conclusion was drawn on the following:

(1) The Teacher and Students use all the categories of the classroom interaction by applying Flanders Interaction Analysis Category (FIAC) model. The categories of classroom interaction easier to find through the data transcription which is coded before. While, pairing the number of categories of interaction is used to enter it into matrix. Then, from the matrix can simplify to calculate each category until get the percentage on it.

(2) The dominant category of Teacher Talk in English classroom Interaction at SMP NEGERI 1 was giving direction (30.92\%). While the lowest category was accepts or uses the ideas of student $(0.19 \%)$. The dominant category of Students Talk was students talk-response(28.81\%) while the lowest categories was student talk initiation $(0.29 \%)$. 


\section{Suggestions}

In line with the conclusion above, some suggestions are recommended as follows:

(1) It is suggested that English teacher should balance their talk in the classroom interaction. The teacher should improve their teaching way in the classroom into a good way.

(2) By applying Flanders Model, it can improve the students to interact actively in the classroom.

(3) It is suggested that the Further research that want to apply Flander's model in the teaching learning process should consider teacher talk and students talk in the whole classroom process.

\section{REFERENCES}

Al-Nawrasy, Omar. 2012. The effect of Native and Nonnative English Language Teacher on Secondary Students' Achievement in Speaking Skills. Jordan Journal of Educational Science, 2012, Vol. 9 No. 2, pp.243-254.

Amatari, Veronica Odiri. 2015. A Review of Flanders' Interaction Analysis in a Classroom Setting. International Journal of Secondary Education, 2015, Vol. 3 No.5, pp. 43-49.

Asmara, Risaning Tias. 2007. An Analysis on The Speaking Classroom Interactions at The Tenth Grade of SMA Negeri 7 Surakarta in The Academic Year 2006/2007. Surakarta : University of Sebelas Maret.

Brown, H Douglas.1994. Teaching by Principles: An Interactive Approach to Language Pedagogy. New Jersey : Prentice Hall.

Brown, H Douglas. 2000. Teaching by Principles: An Interactive Approach to Language Pedagogy. $2^{\text {nd }}$ edn. New York: Longman.

Creswell, John W. 2009. Research Design: Qualitative, Quantitative and Mixed Method Approaches. California: Sage Publication. 
Dagarin, Mateza. 2004. Classroom Interaction and Communication Strategies in Learning English As A Foreign. Sloven: Sloven University.

David, Nunan. 1991. Language Teaching Methodology. Newyork : Prentice Hall.

Eriba, J. O. \& Achor E. E. 2010.Effect of School Type and Teacher Gender on Classroom Interaction Patterns in Integrated Science Class.Brunei International Journal of Science and Mathematics, 2010. Vol. 2, No. 1, pp 48-58.

Halliday,M.A.K.1985.Spoken and Written Language.Victoria:DeakinUniversity Press

Haris, David P. 1974. Testing English as A Second Language. New Delhi: Tata Mcgraw-Hill Publishing.

Harmer, Jeremy. 2001. How to teach English.Edinburgh Gate: AddisonWesley Longman.

Heaton,J. B. 1991. Writing English Language Testing.Cambridge: Cambridge University Press.

Maiza, Masfa. Dwi Rukmini, Ahmad Sofwan. 2015. Teacher'sBasic Questioning Used by English Teacher in Teaching English. English Education Journal, 5 (1), 4.

Pujiastuti, Rini Triani. 2013. Classroom Interaction : An Analysis of Teacher Talk and Student Talk in English for Young Learners (EYL) : University of Education.

Richards, J and T. Rogers. 1986. Approaches and Methods in Language Teaching. Cambridge: Cambridge University Press.

Richard, Jack C. 2008.Teaching Listening and Speaking from Theory to Practice. Cambridge: Cambridge University Press.

Rivers, M. 1981. Teaching Foreign-Language Skills. $2^{\text {nd }}$ ed. Chicago: University of Chicago press.

Sinclair and Coulthard. 1975. Towards an Analysis of Discourse : The English Used by Teachers and Pupils. London: Oxford University Press.

Stubbs, M. 1983. Discourse Analysis: the sociolinguistic analysis of natural language. Oxford: Blackwell. 
Syakur, 1987.Language Testing and Evaluation. Surakarta: Sebelas Maret University Press.

Tias, W Alvita. 2012. An Analysis of Teacher Talk and Students Talk in Speaking Class At The Second Grade Students of Natural Science and Social Science Classes At SMA N 1 Gadingrejo. Lampung: Unversity of Lampung.

Walsh, S. 2011. Exploring Classroom Discourse: Language in Action, London: Routledge.

Yanfen, Liu\& Yuqin, Zhao. 2010. A Study of Teacher Talk in Interactions in English Classes. Chinese Journal of Applied Linguistics (Bimonthly). Vol. 33. No. 2. 